\title{
A construção do ethos discursivo corporativo: o uso de si e noção de competência ${ }^{1}$
}

The construction of the corporate discursive ethos: the use of self and the notion of competence

\author{
Ernani Cesar de FREITAS ${ }^{2 *}$ \\ Universidade Feevale (FEEVALE) \\ Eliane Davila dos SANTOS ${ }^{* *}$ \\ Universidade Feevale (FEEVALE) \\ Ederson de Oliveira CABRAL ${ }^{* * *}$ \\ Universidade Feevale (FEEVALE) \\ Rosana Vaz SILVEIRA**** \\ Universidade Feevale (FEEVALE)
}

RESUMO: O mundo do trabalho e a atividade laboriosa revelam uma distância entre o trabalho prescrito e o trabalho efetivamente realizado nas organizações. A linguagem no, como e sobre o trabalho constrói um mundo normatizado e idealizado, cujas competências corporativas de trabalho posicionam dialeticamente a cultura da empresa e o uso do corposi. Objetiva-se analisar documentos de comunicação do banco Itaú-Unibanco, por meio da compreensão da cena enunciativa construída pela organização. Como marco teórico, utilizam-se postulados da ergologia, no que diz respeito à relação linguagem e trabalho, conforme Schwartz e Durrive (2010); da análise do discurso, com ênfase nos pressupostos enunciativo-discursivos relacionados aos conceitos de cena enunciativa, cenografia e ethos

\footnotetext{
${ }^{1}$ Esta pesquisa teve sua primeira versão nos anais do SXVIII Congresso Internacional, ALFAL2017 e do Seminário Internacional de Pós-graduação (SPG), INOVAMUNDI -2017.

* Pós-doutor em Linguística Aplicada e Estudos da Linguagem e professor da Universidade Feevale, Instituto de Ciências Humanas, Letras e Artes, Novo Hamburgo/RS.

Email: ernanic@feevale.br

** Doutoranda e mestra no Programa de Pós-Graduação em Processos e Manifestações Culturais na Universidade Feevale, Instituto de Ciências Humanas, Letras e Artes, Novo Hamburgo/RS.. eliane.d@feevale.br.

*** Doutorando no Programa de Pós-Graduação em Processos e Manifestações Culturais na Universidade Feevale, Instituto de Ciências Humanas, Letras e Artes, Novo Hamburgo/RS.

E-mail: eder108@yahoo.com.br

**** Doutora no Programa de Pós Graduação em Processos e Manifestações Culturais, da Universidade Feevale, Instituto de Ciências Humanas, Letras e Artes, Novo Hamburgo/RS. Professora nos cursos de Comunicação e Moda, Universidade Feevale. E-mail: rosanavaz@feevale.br
} 
segundo Maingueneau (2008, 2016a). O corpus de pesquisa corresponde a recortes discursivos documentais do banco Itaú-Unibanco que são apresentados no site oficial da instituição.

PALAVRAS-CHAVE: Competências. Cenas enunciativas. Corpo-si. Ethos.

\begin{abstract}
The working world and the laborious activity reveal, in organizations, a distance between prescribed work and actually carried out work. Language of how and about work builds up a regulated and idealized world whose corporate work capabilities place the organization culture and the use of the one who works. The target, herewith, is to analyse communication documents of Itaú-Unibanco bank through the understanding of the declarative scene built up by the organization. As theoretical framework, one uses ergology postulates, where the relation between language and work is regarded, according to Schwartz and Durrive (2010); speech analysis postulates, with an emphasis on declarativediscursive assumptions related to the concepts of declarative scene, scenography and ethos according to Maingueneau (2008, 2016a). The research corpus corresponds to discursive documental pieces of Itaú-Unibanco bank which are presented at the institution official site.
\end{abstract}

KEYWORDS: Skills. Enunciative scene. The one who works. Ethos.

\title{
Introdução
}

A atividade laboral contempla caminhos constituídos pelas experiências de sujeitos e de normas prescritivas que definem a larga distância entre o trabalho indicado e o trabalho efetivamente realizado nas organizações. As normas para a realização de uma tarefa são o prescrito, aquilo que é pré-indicado, pré-determinado pela direção da empresa. No entanto, no decorrer da história empresarial, percebemse modificações nesses processos, configurando-se novas formas de atuação, assim como criação de setores, aquisição de equipamentos, participação de agentes formadores de culturas de treinamento empresarial, entre outros.

Porém, cabe ressaltar que o próprio sujeito em atividade de trabalho influencia o processo instituído, isto é, com seu agir, porque, de acordo com suas vivências, suas formações escolares, seus hábitos, sua cultura familiar, o direciona para uma conduta extremamente subjetiva, o que constituirá o uso do corpo-si. Portanto, pode-se dizer que "este alguém que trabalha - este centro de arbitragens 
que governa a atividade - pode assim ser designado corpo-si ou corpo-pessoa". (DURRIVE; SCHWARTZ, 2008, p. 24).

Não se pode esquecer que o sujeito em situação de trabalho está desempenhando suas próprias funções concomitantemente com outros agentes. É nesse sentido que a ergologia pode se posicionar como uma abordagem fundamental para o reconhecimento de discursos internos, capazes de reverberar na construção da cultura empresarial.

A abordagem ergológica pode auxiliar a verificação de outros processos para o estudo do discurso. Inicialmente, o estudo conceitual sobre o ethos é fundamental para compreender o sujeito em situação de trabalho, sua formação como ser social, devido, inclusive, à representatividade que projeta em seu cargo, no seu contexto laboral. A representação está inserida na linguagem e sua formação constitui uma projeção da cena enunciativa à qual o sujeito se expõe. A análise da cena enunciativa é fundamental para se entender o contexto em que se atua e, acima de tudo, onde a cultura se multiplica, projeta-se, modifica-se. Os agentes das mudanças (prescrição, cultura, ofício, ethos) estão diretamente conectados em diferentes cenografias, as quais, podem contribuir para a abordagem ergológica. Portanto, realiza-se, aqui, um exercício de interface.

Sendo assim, o presente artigo define como questão norteadora estudar de que forma as cenas enunciativas construídas no discurso organizacional contribuem para o entendimento do ethos discursivo - como imagem de si - de uma instituição financeira. Objetiva-se analisar documentos de comunicação externa de uma instituição financeira, por meio da compreensão das cenas enunciativas das quais decorrem o ethos discursivo - como imagem de si - da organização. A pesquisa é aplicada, exploratória e descritiva; faz uso de procedimentos técnicos bibliográficos e documentais, com abordagem qualitativa e com procedimentos de um estudo de caso sobre o banco brasileiro Itaú-Unibanco. Como marco teórico, utilizam-se postulados da ergologia, no que diz respeito à relação linguagem e trabalho, conforme Schwartz e Durrive (2010); da Análise do Discurso, com ênfase nos pressupostos enunciativo-discursivos relacionados aos conceitos de cena enunciativa, cenografia e ethos, segundo Maingueneau (2008, 2016a). 


\section{Ergologia: entender para transformar}

Schwartz e Durive (2010) apontam que a competência é um tema complicado, mas essencial. O termo competência aparece em muitas áreas do conhecimento e, no âmbito da gestão, tem se desenvolvido muito, pois as formas de trabalho estão cada vez mais complexas. Segundo Stroobants (2006, p. 78), nos $\operatorname{anos} 80$

[...] o termo competência saiu do uso corrente para conhecer um sucesso rápido nos meios da formação e do emprego. Os investigadores contribuíram para a sua propagação, sem que, no entanto, se reunisse acordo sobre uma definição rigorosa. Aliás, o entusiasmo por esta noção deve bastante à sua ambiguidade. O seu carácter polissémico abre-lhe vastos horizontes, conciliando especulação e pragmatismo.

Stroobants (2006) ainda aponta que as competências se constituem como construções sociais e seus aspectos devem ser interrogados, a partir das suas diversas aplicações, pois elas estavam, ou ainda podem estar restritas a três referências: a classificação dos empregos, o nível de instrução e a antiguidade.

É importante ressaltar que trar-se-á a noção de competência sob as luzes da abordagem ergológica. A ergologia é uma (in)disciplina - de pensamento-ação que considera toda atividade, inclusive a atividade de trabalho, como matriz de variabilidade, uma vez que é atravessada pelo inédito, pelo evento, pela complexidade (BRITO; ATHAYDE, 2010). Primeiramente, precisa-se esclarecer o que é competência pelo prisma ergológico, pois, se não se tiver essa noção, como far-se-á para objetivá-la, avaliá-la, julgá-la ou separá-la? Competência, na abordagem ergológica, é aquilo que uma pessoa coloca em ação no trabalho e não se relaciona ou restringe ao posto de trabalho. Encontram-se muitas enunciações sucintas daquilo que há para fazer em determinados postos de trabalho, mas a competência não se limita a elas (SCHWARTZ; DURRIVE, 2010). Quando se fala sobre competência, precisa-se observar e reconhecer aquilo que é requerido para se exercer uma atividade, assim conseguir-se-á compreender o que faz uma pessoa em sua atividade laboral. Não basta ter uma lista hipotética de competências para avaliar se uma pessoa as tem ou não, uma vez que a competência é um agir em tempo específico (agora) e em um lugar específico (aqui) nos horizontes da atividade de trabalho, em um meio sempre infiel. Operacionalizar a competência, 
relacionando-a com situações de trabalho abrangentes, sem considerar a infidelidade do meio, ou seja, as variáveis possíveis que estão em jogo, é padronizar o agir, neutralizando as singularidades existentes em cada situação.

A noção de competência, dentro do escopo ergológico, sugere três elementos que se articulam com facilidade: a) a apropriação das normas, do âmbito daquilo que pode ser codificado, do que pode ser transmitido; b) os elementos que fogem da conceitualização, do histórico de qualquer situação de trabalho: o inédito, algo totalmente diferente do prescrito; c) a gestão do inédito, isto é, as escolhas realizadas pelas pessoas diante do inédito, do diferente, daquilo que não é, não foi e não poderá ser prescrito, na qual que se joga com uma dimensão de valores que se articulam com os dois primeiros elementos (SCHWARTZ, 2014; DURRIVE, 2010). Além disso, é preciso interrogar o inédito como matéria estrangeira, que só pode ser apreendida nas relações microscópicas e concretas do cotidiano (RAMMINGER, 2011).

A competência é de natureza heterogênea, incomensurável e incomparável, o que conduz a pensá-la como uma combinação de elementos, ou melhor, de ingredientes que se mesclam, mas são diferentes. Para a ergologia, "um certo número de ingredientes é necessário a todo agir em competência, para cada pessoa, numa dada situação" (SCHWARTZ, 2014; DURRIVE, 2010, p. 207). Dessa forma, como caracterizar esses ingredientes, como compor "o perfil de uma pessoa, o perfil de seu tipo de 'agir em competência' numa determinada situação?' (SCHWARTZ, 2014; DURRIVE, 2010, p. 207, grifo do autor).

A ergologia dispõe de seis ingredientes para auxiliar na visualização da complexidade que está inerente à noção de competência: $1^{\circ}$ ) o protocolo; $2^{\circ}$ ) a emergência da singularidade; $3^{\circ}$ ) a capacidade de articulação entre o protocolar e o singular; $4^{\circ}$ ) o debate de valores; $5^{\circ}$ ) a ativação do potencial pessoal; $6^{\circ}$ ) o reconhecimento das sinergias de competências.

O primeiro ingrediente está relacionado àquilo que é protocolar, ao domínio relativo do aspecto protocolar dos saberes científicos ou técnicos, que podem ser de ordem econômica, gestionária, jurídica, linguística e também da ordem daquilo que pode ser codificável, isto é, de códigos, de saberes, de linguagens e de discursos que enquadram as situações de trabalho. Esse ingrediente é o que antecipa a ação, é 
aquele que cria hipóteses, imagina a situação ideal, com o intuito de avaliar e/ou fixar um comportamento. Está, muitas vezes, antecipado por discursos emblemáticos, fixados nas cartilhas, diretrizes, orientações administrativas, etc. A apropriação desse ingrediente é avaliável, pois é o mais palpável, no entanto, limitar-se a ele neutralizará a complexidade do agir em competência (SCHWARTZ, 2014; DURRIVE, 2010).

O segundo ingrediente dá ênfase à singularidade, pois é uma fusão, um encontro de interfaces dos ambientes técnicos e humanos, tais como procedimentos e hábitos. Consiste na dimensão que supõe capacidades ou competências, essas absolutamente diferentes do primeiro: trata-se da capacidade de se antecipar diante dos espaçamentos das normas, das diretrizes, das orientações. Nele está a “impregnação da história simultaneamente humana, técnica, viva, da situação que permite ao 'agir em conjunto' produzir com desempenho" (SCHWARTZ, 2014; DURRIVE, 2010 p.209, grifo do autor). Esse ingrediente não pode ser contextualizado em um país, em uma cultura, em uma língua, não pode ser antecipado, mas apenas vivido em um aqui e agora específicos em uma situação de trabalho. Tampouco é contextualizado, por isso há a dificuldade de (pré) enunciá-lo, por mais que as instituições, empresas e lugares de atividade tentem fazê-lo.

O terceiro elemento trata da sinergia ou ressonância entre o protocolo e o singular, isto é, "da capacidade de articular a face protocolar à face singular de cada situação de trabalho" (SCHWARTZ, 2014; DURRIVE, 2010, p.210). Cada situação de trabalho é única, embora nela sejam usados os mais diversos tipos de recursos codificados, autorizados pela instância normativa. Esses recursos são regulados pelas pessoas que mobilizam seu agir em competência diante do que cada situação traz de singular. Essa autorregulação implica em debates de valores, na escolha de adaptar-se diante das diretrizes, de se dispor em sinergia com o particular de cada situação. Assim, para que qualquer indivíduo seja eficaz, são necessários conhecimentos protocolares e escolhas pessoais; essa ressonância resultará naquilo que a ergologia chama de trabalho efetivamente realizado.

$\mathrm{O}$ quarto ingrediente trata do debate de valores, que remete "ao estado de uma relação entre a pessoa e o meio, na qual lhe é demandado agir" (SCHWARTZ, 2014; DURRIVE, 2010, p.213). O agir em competência dependerá do que o meio 
dispõe, do que ele oferece às pessoas, não como um espaço de trabalho, mas como um espaço de desenvolvimento de suas aptidões), de manifestação do potencial e de reconhecimento da existência do potencial de cada um em situação de trabalho. Para Schwartz (2014), toda atividade (de trabalho) é uma dramática, na qual há uma arbitragem permanente entre o uso de si por si mesmo (demanda singular e pessoal), e o uso de si pelos outros (demanda dos conjuntos operatórios prescritos). Pode-se dizer que a dramática é o embate entre os valores do corpo-si e as questões impostas pelo meio. O debate de normas é uma dramática permanente dos usos do corpo-si, no qual estão em jogo as motivações, as escolhas que se originam das renormalizações do ser humano (SCHWARTZ, 2014).

No entanto, os preceitos pessoais em atrito com os valores da empresa provocam um debate de normas que culmina sempre em uma escolha, em uma tomada de decisão explícita ou implícita. O meio onde se desenvolve, ou melhor, protagoniza-se a situação de trabalho pode ser um meio que está em equilíbrio com as normas da vida estipuladas e vividas por cada pessoa. Mas, mesmo o meio indo ao encontro das normas de vida singulares, sempre será infiel, sempre haverá algo de inédito e isso conduzirá, constantemente, a um debate de valores.

O quinto ingrediente é a ativação do potencial pessoal, que é um trabalho que a pessoa deve demandar a ela mesma, é o verdadeiro uso de si por si, pois ninguém pode descrevê-la ou prescrevê-la. Trata-se de reconhecer o meio como um espaço de valor para a pessoa. Se a pessoa, por intermédio do corpo-si, observa, reconhece e atribui valor ao meio, todos os ingredientes da competência podem ser potencializados e, consequentemente, desenvolvidos (SCHWARTZ; DURRIVE, 2010). O meio pode ser um catalizador dos possíveis, do potencial, das aptidões que cada sujeito carrega em si. A ativação do potencial é uma verdadeira dramática, pois são colocados em cena não somente o auto(re)conhecimento, a autoobservação, mas também a observação do meio, as possibilidades do protagonismo dos sujeitos, as motivações, a sensibilização dos discursos motivacionais e a contradição dos aspectos inibidores (tempo, verba, espaço, recursos, entendimento, e isso conduz ao sexto ingrediente).

O sexto ingrediente é o reconhecimento das sinergias das competências; trata da criação permanente das circulações coletivas, que são visíveis ou invisíveis, 
formais ou informais, que estão fora das prescrições ou organogramas, porém são a própria vida da atividade, do trabalho (SCHWARTZ; DURRIVE, 2010). Em outras palavras, esse ingrediente trata da capacidade de avaliar para si e para o outro seu próprio perfil de ingredientes. A capacidade de trabalhar em equipe consiste em apreender que cada pessoa, em função de sua história, de sua vida escolar, de suas possibilidades e impossibilidades, de suas experiências de vida tem um perfil singular. Essa capacidade não apenas está apoiada em assumir responsabilidades no momento em que se deve assumi-las, mas também está conexa à diversidade das histórias humanas e ao respeito a essa diversidade, à compreensão de que o trabalho coletivo considera o acionamento desses diversos ingredientes.

Esses seis ingredientes estabelecem uma interação com todas as riquezas do corpo, da inteligência, da cultura e podem ser postos em comunicação em todo instante de trabalho. Além disso, eles nutrem, ao agir em competência, pois, considerando-os, pode-se analisar e objetivar o que os discursos empresariais esperam que as pessoas coloquem nas situações de trabalho.

\section{A cena enunciativa e o ethos discursivo: imagens da organização}

A questão do ethos vem sendo estudada desde a antiguidade e sua concepção discutida a partir dos estudos de Aristóteles sobre retórica. A noção de ethos estava ligada à persuasão - o elemento constituinte da arte. Nesse entendimento, o "ethos consiste em causar boa impressão mediante a forma como constrói o discurso, em dar uma imagem de si capaz de convencer o auditório, ganhando sua confiança" (MAINGUENEAU, 2008, p.56). A retórica antiga resume-se a um triângulo caracterizado pelo logos, pathos e o ethos. O logos referese à lógica do puro argumento e aos tipos de argumentos empregados. O pathos refere-se aos tipos de apelo e reconhecimento dado à audiência, levando em consideração a psicologia social das emoções. Nesse sentido, o orador deveria dispor de três características morais que garantissem sua credibilidade, tais como: prudência, virtude e benevolência; o ethos também tem uma dimensão social; é adequado ao seu habitus e suas posturas corporais. A dimensão sociológica de interpretação da noção retórica de ethos situa os trabalhos de Pierre Bourdieu, que 
propôs uma reinterpretação da noção de ethos no quadro do conceito de "habitus, designando o conjunto dos princípios interiorizados que guiam nossa conduta e nossas posturas em relação ao corpo igualmente interiorizadas" (AMOSSY, 2016, p. 26).

Assim, a análise das instâncias de enunciação é desdobrada em três cenas distintas: a cena englobante, a genérica e a cenografia. A cena englobante é caracterizada pelo tipo de discurso (religioso, publicitário, político, etc.). Já a cena genérica é constituída com base nos diversos tipos de gênero de discurso que, neste estudo, caracteriza-se como um pronunciamento político. No entanto, não é por meio de nenhuma das cenas que Maingueneau (2013) relata o confronto dos sujeitos interlocutores, mas pela cenografia, que não é imposta pelo tipo de gênero de discurso, mas instituída pelo próprio discurso. No que diz respeito à cenografia, ela não é prescrita "pelo gênero, ela é construída pelo próprio texto: um sermão pode ser enunciado por meio de uma cenografia professoral, profética etc." (MAINGUENEAU, 2016a, p.75).

A cenografia, como o ethos que dela participa, implica um processo de enlaçamento paradoxal: desde sua emergência, a fala supõe uma certa cena de enunciação que, de fato se valida progressivamente por essa mesma enunciação. A cenografia é, assim, ao mesmo tempo, aquela de onde o discurso vem e aquela que ele engendra (MAINGUENEAU, 2016a, p.77).

O ethos possibilita pensar com mais abrangência sobre a aderência dos sujeitos a um posicionamento discursivo. "O termo posicionamento trata-se de uma categoria de base da análise do discurso, que diz respeito à instauração e à conservação de uma identidade enunciativa" (CHARAUDEAU; MAINGUENEAU, 2012, p. 392). Acredita-se que o documento comunicacional do Itaú-Unibanco se origina de uma voz própria que diferencia a organização no processo enunciativo, como sugere Mikhail Bakhtin (2000). Assim, pode-se dizer que o discurso comporta um tom, oral ou escrito, o qual "se apoia sobre uma dupla figura do enunciador, a de um caráter e de uma corporalidade, estreitamente associadas" (MAINGUENEAU, 2008, p. 92). O tom é compreendido como um valor social, ou seja, um relevo ou um sentido dado à palavra no contexto em que a enunciação é articulada e compreendida por quem recebe a informação.

O tom oportuniza ao receptor do discurso construir "uma representação do 
corpo enunciador, fazendo emergir uma instância subjetiva que desempenha o papel de fiador do que é dito". (MAINGUENEAU, 2013, p. 98). O fiador é aquele que se revela no discurso, quando, dotado de "propriedades físicas (corporalidade) e psicológicas (caráter)" se constitui de representações baseadas no estereótipo julgado pela sociedade (MAINGUENEAU, 2016b, p. 14). A partir dessa ideia, "este é o tipo de fenômeno que, por desdobramento da retórica tradicional, pode se chamar de ethos: por meio da enunciação, revela-se a personalidade do enunciador" (MAINGUENEAU, 2013, p.97-98). A maneira de dizer, que é também um modo de ser, possibilita a adesão do leitor, que é expressa pelo conceito de incorporação que exerce três finalidades: a enunciação confere uma corporalidade ao fiador, ela lhe dá corpo; o destinatário incorpora, assimila através da enunciação um conjunto de esquema que corresponde a uma maneira específica de se relacionar com o mundo; essas duas primeiras incorporações permitem a constituição de um corpo, da comunidade imaginária dos que aderem ao mesmo discurso. (MAINGUENEAU, 2016b, p. 14).

Além disso, a incorporação pressupõe um mundo ético do qual o fiador participa, isto é, pressupõe cenários estereotipados alusivos a elementos verbais e não verbais. A tomada de consciência, as visões de mundo, as opiniões que as organizações possuem são confrontadas a partir das relações dialógicas e valorativas de outras instituições. As identidades são cogitadas como construções que determinam a coerência concebida frente às questões das fragmentações e dispersões dos indivíduos que estão em constante transformação, gerando também fragmentações dos códigos culturais e multiplicidade de estilos que resultam no pluralismo cultural (HALL, 1997). Ao utilizar a linguagem, as empresas representam seus valores e culturas. Os significados, de acordo com Hall (1997), são gerados com base em uma representação de mundo que é compreendida e reconhecida por cada cultura.

É importante realçar que a problemática do ethos quanto à sua eficácia, em diversos textos, motivou Maingueneau (2016b) a atribuir-lhe três dimensões (categórica, experiencial e ideológica).

A dimensão categórica abrange os "papéis discurso ou extradiscursivos. Os papéis discursivos são aqueles relacionados à atividade de fala: animador, contador de histórias, pregador. Os estatutos extradiscursivos 
podem ser de natureza muito variada: pai de família, funcionário, médico, camponês, americanos, solteiros, etc.; a dimensão experiencial do ethos abrange as caracterizações sócio-psicológicas estereotipadas, associadas às noções de incorporação e de mundo ético: bom senso e lentidão do campo, dinamismo do jovem executivo; a dimensão ideológica se refere a alguns posicionamentos dentro de um campo: feminista, de esquerda, conservador ou anticlericais". (MAINGUENEAU, 2016b, p. 15).

Além disso, destaca-se que o ethos está crucialmente ligado ao ato de enunciação, mas não se pode desconsiderar que o coenunciador constrói uma imagem do orador. Dessa forma, afirma-se a existência de uma diferenciação entre o ethos pré-discursivo e o ethos-discursivo. Maingueneau (2008) evidencia que essas imagens prévias que se elaboram do orador estão fundamentadas em representações culturalmente partilhadas. Quando se pensa em ethos discursivo, esse é vinculado a resultados da interação de diversos fatores: ethos pré-discursivo (ethos prévio), ethos discursivo (ethos mostrado), mas também a "os fragmentos do texto nos quais o enunciador evoca sua própria enunciação (ethos dito)" diretamente - 'é um amigo que lhe fala' ou 'indiretamente, por meio de metáforas ou de alusões a outras cenas de fala, por exemplo". (MAINGUENEAU, 2011, p. 18). A diferença entre o ethos dito e o ethos mostrado se inscreve nos limites de uma linha; é muito difícil definir uma fronteira cristalina. O ethos efetivo resulta da interação entre as diversas esferas. A Figura 1 mostra o ethos efetivo e permite a compreensão da dinâmica e da complexidade na construção do ethos.

Figura 1: Ethos

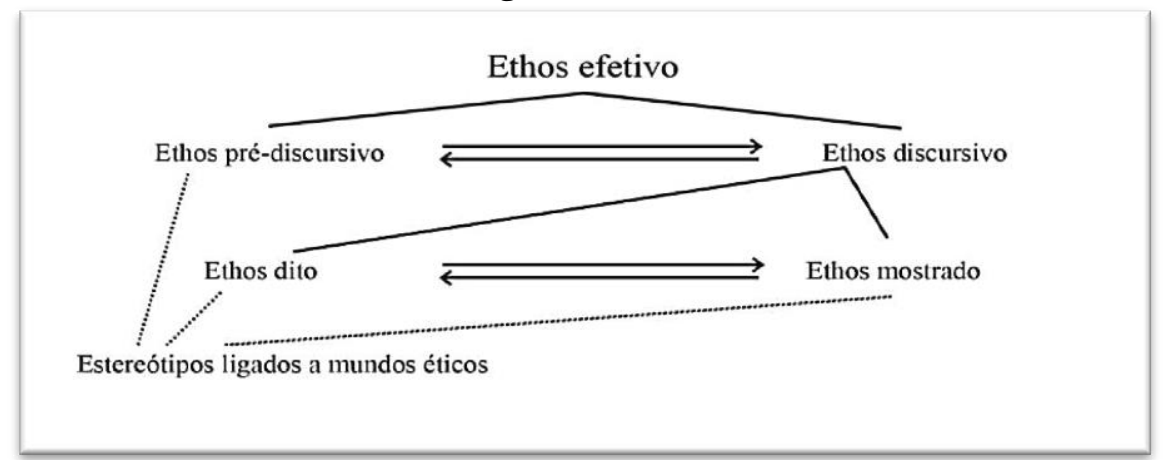

Fonte: Maingueneau (2008, p.71)

Pode-se depreender que é a partir do ato da enunciação que algo do ethos é liberado: por meio do jeito de falar, o locutor desperta no coenunciador a elaboração de determinada representação de si. Portanto, o ethos é parte constitutiva da cena 
enunciativa e não é uma estratégia de persuadir o coenunciador. Além disso, destaca-se que esse locutor não é homogêneo, mas sim heterogêneo, eivado por diversas vozes e forças sociais que atuam em seu discurso.

\section{Essência metodológica}

A essência metodológica do estudo recorre às recomendações de Prodanov e Freitas (2013). A pesquisa é aplicada, exploratória e descritiva; segue procedimentos técnicos bibliográficos e documentais, com abordagem qualitativa, e é feita sob a configuração de um estudo de caso. O corpus de pesquisa corresponde a recortes discursivos documentais do banco Itaú-Unibanco que são apresentados no site oficial da instituição em 2012. O critério de escolha do objeto empírico que aborda os sete pontos valorados pela instituição, no que tange às questões de competência funcional esperada de cada funcionário, possibilita um exercício metodológico para cotejar as teorias acionadas neste estudo. O critério de escolha do objeto empírico também se deu em razão da disponibilidade do documento no site oficial do banco na internet.

A materialidade discursiva de comunicações organizacionais promove reflexões sobre o mundo do trabalho e as distâncias entre o que se entende por trabalho prescrito e trabalho efetivamente realizado. A linguagem no, como e sobre o trabalho pode lançar luzes sobre as cenas enunciativas e dos ethé construídos para explicitar as competências funcionais idealizadas pela organização e o uso do corpo-si. Seguindo o aporte teórico do estudo, organizam-se as categorias, que concebem o dispositivo que referencia a análise do corpus (Figura 2).

Figura 2- Dispositivo Epistemológico de análise 


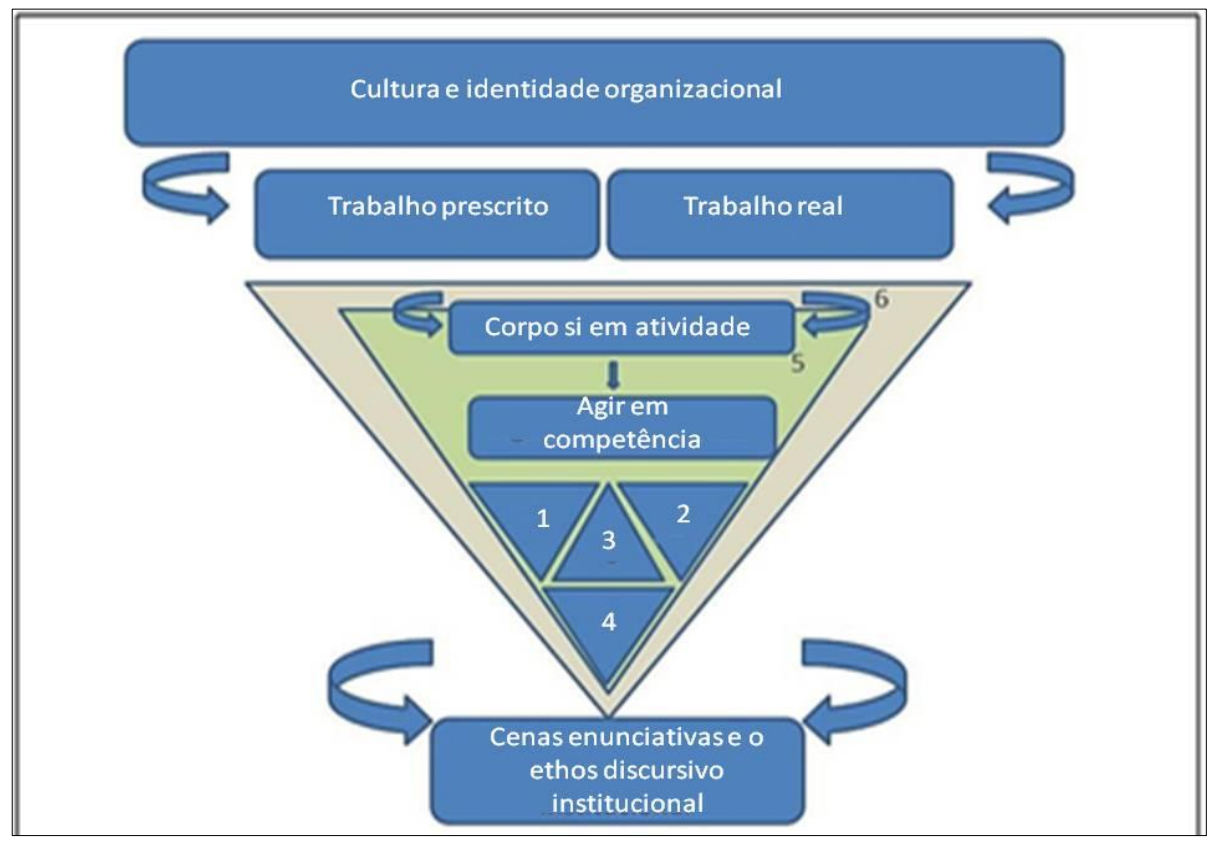

Fonte: Elaborada pelos autores

O roteiro direciona à compreensão de que a organização, ao apresentar seus valores culturais e sua identidade, em situações de trabalho prescritas e reais, evoca o corpo-si a um agir em competência. A sinergia dos ingredientes desse agir em competência leva ao entendimento das competências idealizadas para seus funcionários, das cenas enunciativas e o do ethos discursivo - como imagem de si da instituição financeira. Em contrapartida, a Figura 1 sugere que é preciso agir em competência, uma vez que existe uma lacuna entre o trabalho prescrito e o trabalho real. O entendimento do protagonismo do corpo-si na atividade de trabalho e a ênfase nos seis ingredientes em sinergia, auxilia a construção de uma abordagem que evidencia uma bifurcação da noção de competência nas empresas (MAINGUENEAU, 2008; SCHWARTZ; DURRIVE, 2010).

Conforme sugere o dispositivo na Figura 2, a análise segue as seguintes categorias teóricas:

a) Linguagem e trabalho, e o agir em competência: utilizam-se dos postulados da ergologia, conforme Schwartz e Durrive (2010), no que diz respeito às questões relativas à linguagem e trabalho, assim como a uma visão mais abrangente sobre o agir em competência, contrapondo-se à visão apenas pautada em noções prescritivas no trabalho.

b) Cenas de enunciação e ethos institucional: a categoria teórica, por meio 
da perspectiva enunciativo-discursiva de Maingueneau (2008, 2016a), abarca questões da cena enunciativa e os desdobramentos que engendra a construção do ethos discursivo.

A metodologia está organizada da seguinte forma: primeiramente, apresenta-se o corpus de pesquisa.

\section{Nosso jeito: banco Itaú-Unibanco}

Nesta etapa, apresenta-se o documento comunicacional com as informações sobre o Nosso Jeito, enunciado da campanha publicitária do banco Itaú-Unibanco, ou seja, a materialidade discursiva que compõe o recorte deste estudo. O banco Itaú-Unibanco Holding S.A. é uma instituição brasileira, com atuação internacional, fundada em 1924. O banco nasceu em Poços de Caldas (MG) e tem cerca de cinco mil agências no Brasil e no exterior, com atuação em mais de vinte e um países.

Destaca-se que, em 2008, o banco Itaú e o banco Unibanco realizaram uma fusão que resultou na unificação de duas culturas organizacionais, "que culminou em juntar, sob a mesma bandeira financeira, duas empresas antes independentes com duas culturas distintas que, até então, eram concorrentes" (SANTOS, 2015, p. 113). Observa-se que o Itaú-Unibanco, por meio do Nosso Jeito, em 2012 unificou os valores e crenças das duas instituições e sintetizou a cultura corporativa em sete premissas que são apresentados no Quadro 1.

\section{Quadro 1- Nosso Jeito}




\section{Conheça o Nosso Jeito, que faz o Itaú Unibanco inconfundível. Nosso Jeito}

1 Só é bom para a gente, se for bom para o cliente Somos pessoas servindo pessoas, com paixão e excelência. Trabalhamos com o cliente e para o cliente, porque ele é a razão maior de tudo o que fazemos.

2. Fanáticos por performance A geração de resultados sustentáveis está no nosso DNA. O desafio constante de buscar a liderança em performance nos trouxe até aqui e continuará guiando a nossa empresa em direção aos nossos objetivos.

3 Gente é tudo para a gente Tudo o que realizamos é por meio de gente. Gente de talento, que gosta de trabalhar em um ambiente de colaboração, meritocracia e alta perfomance.

4 O melhor argumento é o que vale Cultivamos um ambiente desafiador, aberto ao questionamento e ao debate construtivo. Para nós, a hierarquia que conta é a da melhor ideia.

5 Simples, Sempre Acreditamos que a simplicidade é o melhor caminho para a eficiência. Por isso, lutamos para que a profundidade não se confunda com complexidade e para que a simplicidade não se transforme em simplismo.

6 Pensamos e agimos como donos Pensamos sempre como donos da empresa, liderando pelo exemplo e colocando os objetivos coletivos acima da ambição pessoal.

Ética é inegociável Fazemos o que é certo, sem jeitinho, sem atalhos. Exercemos nossa liderança de forma transparente e responsável, totalmente comprometidos com a sociedade e com as melhores práticas de governança e gestão.

\section{Fonte: seção de cultura corporativa Itaú (2017)}

O documento comunicacional do Itaú apresenta sete premissas da instituição que devem ser seguidas pelos seus funcionários e é como uma cartilha para posicionamentos culturais e valorativos da organização. O Nosso Jeito é, na verdade, um conjunto de atitudes que o banco espera reconhecer em cada funcionário da instituição. O Nosso Jeito diferencia banco Itaú no mercado financeiro e revela a cultura corporativa da instituição.

No próximo item, apresentam-se as análises e resultados do estudo.

\section{Rumo às análises e aos resultados}

As análises e resultados do estudo, a partir do corpus mencionado no item anterior, apresentam as seguintes categorias teóricas; Linguagem e trabalho, e o agir em competência e Cenas de enunciação e ethos institucional.

A linguagem e trabalho, e o agir em competência, no banco Itaú-Unibanco, por meio da materialidade linguística, não dá margens para a renormalização, sempre inevitável, pois não somente desconsidera os inéditos, como também 
apresenta uma crença na fidelidade do meio, visando apenas o primeiro ingrediente, ou seja, ao trabalho prescrito, não dando espaço para os debates de valores. Algumas pistas discursivas dão zelo excessivo ao ato do fazer puro e simples, tais como - “A geração de resultados sustentáveis está no nosso DNA. O desafio constante de buscar a liderança em performance nos trouxe até aqui e continuará guiando a nossa empresa em direção aos nossos objetivos”. Tal enunciado remete, apenas, à execução de tarefas, como se o prescrito totalizasse o agir em competência. Mas, para a ergologia, o agir em competência mobiliza diferentes ingredientes (SCHWARTZ; DURIVE, 2010). Uma pessoa age em competência em vista de objetivos, no entanto, o termo "fanático" expresso no título desse item, foge de ser uma figura de linguagem e remete ao ato de execução de tarefas. Quando se executa bem uma função, independentemente do objetivo final, embora esse apareça como geração de resultados sustentáveis, o agente da situação de trabalho está orientado por uma automatização do fazer.

Nas pistas textuais: "Tudo o que realizamos é por meio de gente. Gente de talento, que gosta de trabalhar em um ambiente de colaboração, meritocracia e alta performance" - embora o enunciado remeta a um ambiente de colaboração, não está explícito como ele é construído. A colaboração faz parte do sexto ingrediente e é valorizada na abordagem ergológica, pois potencializa as ações dos sujeitos; contudo, a meritocracia está ligada às capacidades e às realizações atingidas individualmente, o que pode ampliar a concorrência no seio do coletivo de trabalho, a ponto de ser assimilada a um instrumento de gestão pelo stress (STROOBANTS, 2006). Portanto, o enunciado levanta questionamentos, pois nem todas as pessoas terão as mesmas capacidades, nem todos agem no mesmo tempo e do mesmo modo para chegar às metas desejadas. A meritocracia é uma tentativa de impulsionar as atividades nas situações de trabalho, no entanto premia as pessoas que atingem um resultado superior, o que neutraliza, muitas vezes, a colaboração.

Outra pista discursiva mostra o paradoxo existente no enunciado corporativo: "Pensamos sempre como donos da empresa, liderando pelo exemplo e colocando os objetivos coletivos acima de ambição pessoal - um espaço permeado pela meritocracia dá margens para o cultivo da ambição pessoal”, pois nele, todas as pessoas estão cientes de seu status social e se empenham para alterá-lo, para 
aprimorá-lo, o que pode construir um espaço de competitividade e de avaliação das competências por metas atingidas, o que resultará na eleição de um vencedor e não na eficácia de um coletivo. Sendo assim, diante da construção linguageira, houve a possibilidade da verificação do prescrito. A demonstração das orientações da "nova" organização, enfatizada na concepção da cena genérica inspirada no estilo de comunicação do banco Itaú (jovem, cor laranja), apoiado na cenografia construída em consonância com atributos da experiência dos funcionários das duas corporações ("inconfundível”), assim, mesclados na fusão.

Nas cenas de enunciação e ethos institucional, seguindo o trajeto teórico e metodológico proposto, destaca-se a construção das cenas enunciativas que se desdobram em 1) cena englobante: discurso do tipo institucional; 2) cena genérica: construção de um anúncio de comunicação externa; 3) a cenografia: procura trazer ao discurso a possibilidade dos leitores, funcionários ou atuais empregados da instituição serem interpelados a assumir um compromisso com a cultura do banco, evidenciando os ingredientes mais valorizados pela instituição. $\mathrm{O}$ convite à cenografia enunciada sugere a apresentação da essência cultural e identitária da empresa. A materialidade discursiva Nosso Jeito suscita que as escolhas de valores e crenças do banco Itaú-Unibanco devam ser o jeito daquele indivíduo que venha participar do quadro funcional da instituição. Ao mesmo tempo em que a empresa apresenta sua cultura, manifesta os ingredientes que valorizará no perfil funcional que deseja. A pista enunciativa agimos como donos, sugere que a cultura da empresa é que deve prevalecer, visto que os objetivos coletivos ficarão acima de ambição individual. Observa-se que o tom (MAINGUENEAU, 2006b) utilizado na comunicação evidencia a forma normativa com que a empresa se relaciona com os comportamentos dos sujeitos dentro da instituição, prescrevendo as ações de cada funcionário, o que também se pode verificar na pista discursiva: só é bom para a gente, se for bom para o cliente. $\mathrm{O}$ funcionário elabora uma representação do enunciador que coloca o site como fiador do discurso da própria instituição (MAINGUENEAU, 2016b).

O ethos prévio remete à ideia de que o banco é uma instituição com credibilidade e que possui uma gestão participativa, sendo uma das empresas líderes no segmento e reconhecida como uma das melhores empresas para se trabalhar. 
Conforme o ethos mostrado, ou seja, a partir do movimento enunciativo que ocorre no processo de discursivização, pode-se depreender que o banco Itaú-Unibanco é uma empresa que valoriza o cliente. A empresa pouco enfatiza a singularidade do funcionário, devido às ações prescritivas de acordo com o que o cliente precisa e com o que a instituição acredita ser um padrão de atendimento.

As materialidades enunciativas: pensamos e agimos como donos, pensamos sempre como donos da empresa, liderando pelo exemplo e colocando os objetivos coletivos acima de ambição pessoal, mostram uma maneira de dizer que sugere que os funcionários devam seguir as normas prescritivas e comportamentais no, como e sobre o trabalho. O ethos dito, conforme as pistas fazemos o que é certo, sem jeitinho, sem atalhos. Exercemos nossa liderança de forma transparente e responsável, totalmente comprometidos com a sociedade e com as melhores práticas de governança e gestão, manifesta o quanto a instituição exerce um ethos de liderança e prescrição. Percebe-se que o banco constrói um caráter e uma corporalidade que são revelados no seu modo de dizer, apresentando a maneira de ser do banco. Em que pese, nas materialidades discursivas, a afirmação o melhor argumento é o que vale, cultivamos um ambiente desafiador, aberto ao questionamento e ao debate construtivo; para nós, a hierarquia que conta é a da melhor ideia, sugere que a empresa não parece ter argumentos suficientes para se deixar perceber como uma organização que dá ênfase às singularidades dos funcionários e está preocupada com uma visão de competência mais abrangente. As marcas discursivas tudo o que realizamos é por meio de gente. Gente de talento, que gosta de trabalhar em um ambiente de colaboração, meritocracia e alta perfomance, sugere uma cartilha para os possíveis funcionários da empresa. A cenografia do discurso do banco se apoia em cenas de fala (validadas), ou seja, já instauradas na memória coletiva e que se firmam em estereótipos que o mercado empresarial e a mídia popularizam nos meios de comunicação.

\section{Considerações finais}

O estudo baseou-se no entendimento da construção das cenas enunciativas do ethos no ambiente de trabalho, analisando as articulações discursivas diante das 
premissas ergológicas instituídas na comunicação externa da instituição financeira. Evidenciou-se que a cultura empresarial está inserida no discurso, ao passo que o trabalhador atribui sua cultura por meio do uso de si na corporação.

A questão norteadora permitiu confirmar o pressuposto de que as cenas enunciativas construídas no discurso organizacional contribuem para o entendimento do ethos discursivo - como imagem de si - de uma instituição financeira. Atingiu-se o objetivo de analisar documentos de comunicação externa da instituição financeira por meio da compreensão da cena enunciativa da qual decorre o ethos discursivo - como imagem si - da organização. As cenas elaboradas discursivamente direcionam à construção de um ethos do Itaú-Unibanco que se apresenta como um banco líder e que sugere ser altamente prescritivo nas normas e competências idealizadas para seus funcionários.

Assim, propõe-se que o funcionário ou corpo-si, ao tentar se inserir na cenografia corporativa com outros trabalhadores, neste estudo de caso, não é acionado a contribuir para o novo prescrito. $\mathrm{O}$ entendimento do protagonismo do corpo-si na atividade de trabalho e a ênfase nos seis ingredientes em sinergia podem auxiliar na construção de uma abordagem que evidencia a bifurcação da noção de competência nas empresas. Contudo, a ergologia orienta-se por meio de competências, nas quais o sujeito é observado.

As competências estão no saber fazer, na gestão do uso do corpo-si, não necessariamente na área de atuação, mas no ambiente (cenografia) e nas diferentes cenas atribuídas ao ethos. O estudo corroborou a ideia de alargamento do conceito de competência que conjectura seis ingredientes: o protocolo; a emergência da singularidade; a capacidade de articulação entre o protocolar e o singular; o debate de valores; a ativação do potencial pessoal; o reconhecimento das sinergias de competências. Tais ingredientes são categorizados como um processo fundamental da metodologia ergológica para o uso de si, cabendo o esforço da análise discursiva para a interpretação da formação do ethos. Consequentemente, percebeu-se que os estudos ergológicos, por meio dos seus seis ingredientes, possibilitaram a consolidação do processo do ofício, podendo ser considerados como aliados para os estudos de análise do discurso. 


\section{REFERÊNCIAS}

AMOSSY, R. Da noção retórica de ethos à análise do discurso. In: AMOSSY, R. (Org.). Imagens de si no discurso: a construção do ethos. 2. ed. São Paulo: Contexto, 2016, p. 9-28.

BAKHTIN, M. Estética da criação verbal. Tradução Maria Ermantina Galvão. 3. ed. São Paulo: Martins Fontes, 2000.

BRITO, J.; ATHAYDE, M. Ergologia e um livro-ferramenta, uma tecelagem que se propaga. In: SCHWARTZ, Yves, DURRIVE, Louis (Orgs.). Trabalhoe Ergologia: conversas sobre a atividade humana. Niterói: Editora da UFF, 2010.

CHARAUDEAU, P.; MAINGUENEAU, D. Dicionário de análise do discurso. 3. ed. São Paulo: Contexto, 2012.

DURRIVE, Louis; SCHWARTZ, Yves. Revisões temáticas: glossário da Ergologia. Laboreal, v. 4, n. 1, p. 23-28, 2008. Disponível em: http://laboreal.up.pt/files/articles/2008_07/pt/23-28pt.pdf. Acesso em: $22 \mathrm{fev}$. 2018.

FACIN, D. O enlaçamento enunciativo de um ritual carnavalizado: cenografia e ethos discursivo em sambas-enredo de escolas carnavalescas do Meio-Oeste catarinense. 120 f. 2012. Dissertação (Mestrado em Letras) - Universidade de Passo Fundo, Passo Fundo, 2012. Disponível em: https://secure.upf.br/pdf/2012DeboraFacin.pdf. Acesso em: 29 mar. 2017. FREITAS, E. C. de. Linguagem na atividade de trabalho: ethos discursivo em editoriais de jornal interno de empresa. Desenredo - Revista do Programa de PósGraduação em Letras da Universidade de Passo Fundo, v. 6, n. 2, p. 170-197, jul./dez. 2010.2 Disponível em: http://www.upf.br/seer/index.php/rd/article/view/1714/1131. Acesso em: 10 mar. 2017.

HALL, S. The work of representation. In: HALL, S. (Org.) Representation. Cultural representation and cultural signifying practices. London/Thousand Oaks/New Delhi: Sage/Open University, 1997.Disponível em: http://www.sagepub.com/upm-data/55352_Hall_ch_1.pdf . Acesso em: 29 mar. 
2017.

. Da Diáspora: identidades e mediações culturais. Tradução Adelaide La Guardia Resende et al. Belo Horizonte: Ed. da UFMG, 2009.

ITAÚ. Cultura corporativa. Disponível em: https://www.Itaú.com.br/sobre/quemsomos/cultura-corporativa/ . Acesso em: 29 mar. 2017.

MAINGUENEAU, Dominique. Cenas da enunciação. POSSENTI, S.; SILVA, M. C. P. de S. e. (Org.). São Paulo: Parábola Editorial, 2008.

A propósito do Ethos. In: MOTTA, A. R.; SALGADO, L. (Org.). Ethos discursivo. 2. ed. São Paulo: Contexto, 2011. p. 11-32.

. Análise de textos de comunicação. 6. ed. São Paulo: Cortez, 2013.

. Ethos, cenografia, incorporação. In: AMOSSY, R. (Org.). Imagens de si no discurso. 2. ed. São Paulo: Contexto, 2016a. p. 69-91.

Retorno crítico sobre o ethos. In: BARONAS, R. L.; MESTI, P. C.; CARREON, R. de O. (Org.). Análise do discurso: entorno da problemática do ethos, do político e de discursos constituintes. Campinas: Pontes, 2016b. p. 13-33.

PRODANOV, C. C.; FREITAS, E. C. de. Metodologia do trabalho científico : métodos e técnicas da pesquisa e do trabalho acadêmico. 2. ed. Novo Hamburgo: Feevale, 2013. Disponível em: http://www.feevale.br/Comum/midias/8807f05a14d0-4d5b-b1ad-1538f3aef538/E-

book\%20Metodologia\%20do\%20Trabalho\%20Cientifico.pdf. Acesso em: 29 mar. 2017.

RAMMINGER, Tatiana. Objeto de estudo ou matéria estrangeira? Contribuições da análise filosófica de Yves Schwartz para os estudos sobre o trabalho. Cadernos de Psicologia Social do Trabalho, São Paulo, v.14, n. 1, 2011. p.1-12.

SANTOS, E. D. dos. Simulacros organizacionais: cultura e identidade como imagem de si corporificada no discurso institucional. 166 f. 2015. Dissertação (Mestrado em Processos e Manifestações Culturais) - Universidade Feevale, Novo Hamburgo, 2015. Disponível em: http://biblioteca.feevale.br/Dissertacao/DissertacaoElianeDSantos.pdf. Acesso em: 29 mar. 2017.

SCHWARTZ, Y. Motivações do conceito de corpo-si: corpo-si, atividade, experiência. Letras de Hoje. Porto Alegre, v. 49, n. 3, 2014 
SCHWARTZ , Y; DURRIVE, L.. Trabalho e Ergologia: conversas sobre a atividade humana. Niterói: Editora da UFF, 2010.

STROOBANTS, M. Competência. Laboreal, v.2, n.2, 2006 p. 78-79. Disponível em: $\quad$ http://laboreal.up.pt/revista/artigo.php?id=37t45nSU547112278541422861. Acesso em: 20 jan. 2018. 